\title{
Genetic Diversity of Andean Tuber Crop Species in the in situ Microcenter of Huanuco, Peru
}

\author{
M. Malice,` J. P. Bizoux, R. Blas, and J. P. Baudoin
}

\begin{abstract}
Andean tuber crop species oca (Oxalis tuberosa Molina), ulluco (Ullucus tuberosus Caldas), and mashua (Tropaeolum tuberosum Ruiz \& Pav.) play major roles in Andean communities. These species show high variability but are threatened with genetic erosion. To study the management of genetic resources of neglected vegetatively propagated crop species, we studied genetic diversity and structure of these species in an in situ diversity microcenter (Huanuco, Peru). A sample of 15 varieties of oca, 15 of ulluco, and 26 of mashua was analyzed with the inter simple sequence repeats (ISSR) molecular markers. Mean genetic distances and global genetic diversities were high for the three species, with higher values for mashua than for oca and ulluco. Assignment technique divided both oca and ulluco samples into two genetic clusters; the mashua sample probably belongs to a single genetic cluster. Inter simple sequence repeats (ISSR) technique showed intravarietal genetic variability for most varieties, suggesting an underestimation of the in situ genetic variability. These results are discussed considering how variation in breeding systems and farmers' practice influenced patterns of genetic diversity. Our findings confirm the hypothesis of a considerable amount of variability found in neglected Andean tubers and are essential to deserve adequate conservation strategies and to maintain genetic resources of neglected Andean tuber crop species under a threat of genetic erosion.
\end{abstract}

M. Malice and J.P. Baudoin, Univ. of Liege, Gembloux Agro-Bio Tech, Tropical Crop Husbandry and Horticulture, Passage des Déportés 2, 5030 Gembloux, Belgium; J.P. Bizoux, Univ. of Liege, Gembloux Agro-Bio Tech, Biodiversity and Landscape Unit, Passage des Déportés 2, 5030 Gembloux, Belgium; R, Blas, Universidad Nacional Agraria La Molina, Crop Husbandry Department, Ap. 456, Lima 12, Peru. J-P. Bizoux is a postdoctoral researcher of FRS-FNRS. Received 2 Sept. 2009. *Corresponding author (Marie.Malice@ulg.ac.be).

Abbreviations: CI, confidence interval; $F_{\mathrm{ST}}$, degree of genetic differentiation; $H_{\mathrm{T}}$, global species genetic diversity; ISSR, inter simple sequence repeats; PIC, polymorphic information content.

$\mathrm{T}$ he Andean region is one of the most important areas of domestication and diversification of crop plants, accounting for a high percentage of crop genetic resources in the world (40\%; Castillo, 1995). Some species from the Andes, such as potatoes (Solanum sp.), have spread across the world and are widely produced, whereas most of the Andean species are still scarcely known outside the Andes (Cárdenas, 1989; Arbizu et al., 1997; Cadima Fuentes, 2006). Among these are three species of Andean tuber crops: oca (Oxalis tuberosa Molina), ulluco (Ullucus tuberosus Caldas), and mashua (Tropaeolum tuberosum Ruiz \& Pav.).

Oca, ulluco, and mashua constitute, together with the potato species, Andean farmers' staple crops (Hernández Bermejo and León, 1992). They are cultivated for their edible tubers in Andean farming systems of high altitudes (from 2500 to $4000 \mathrm{~m}$ above sea level; Cárdenas, 1989; Cadima Fuentes, 2006). Regarding the reproductive systems, fruit and seed production are marginal for oca and ulluco (Gibbs, 1976; Trognitz et al., 1998; Pietilä and Jokela, 1994), whereas mashua flowers profusely and sets many viable seeds with

Published in Crop Sci. 50:1915-1923 (2010).

doi: 10.2135/cropsci2009.09.0476

Published online 1 July 2010.

(C) Crop Science Society of America | 5585 Guilford Rd., Madison, WI 53711 USA

All rights reserved. No part of this periodical may be reproduced or transmitted in any form or by any means, electronic or mechanical, including photocopying, recording, or any information storage and retrieval system, without permission in writing from the publisher. Permission for printing and for reprinting the material contained herein has been obtained by the publisher. 
high germination rates (Grau et al., 2003). But under farming conditions, propagation of these three species is exclusively made through tubers, and botanical seed propagation by farmers has never been observed (Hernández Bermejo and León, 1992). In spite of this, oca, ulluco, and mashua possess a high level of phenotypic diversity, especially in their tuber colors and shapes (Popenoe, 1989; Cadima Fuentes, 2006). In fact, for generations, farmers in Andean communities have developed complex farming systems and used diverse agricultural practices and planting procedures to cultivate crop populations in environments that are heterogeneous and unpredictable (Castillo, 1995). At present, farmers continue to maintain and plant variable pools of Andean tuber varieties to lower the risk of crop failure and to increase food security (Terrazas and Valdivia, 1998). A high degree of genetic diversity created by the early Andean people and by nature (Castillo, 1995) is still maintained by farmers (Ortega, 1997; Terrazas and Valdivia, 1998; Terrazas et al., 2007). However, in the Andes, as in many areas of the world, crop diversity and associated indigenous knowledge are being lost. Genetic erosion relative to oca, ulluco, and mashua is viewed as a consequence of the marginalization of the species and pressures such as increased population, poverty, land degradation, environmental change, introduction of modern crop varieties, and integration into national market economies (Hernández Bermejo and León, 1992; Tapia and Estrella, 2001). On a small scale, genetic erosion observed in oca, ulluco, and mashua could endanger their adaptation to the fluctuating environmental conditions that characterize the Andes (Altieri and Merrick, 1987; Iriondo et al., 2008). Longer-term adaptation to a fluctuating and heterogeneous environment may thus be compromised (Brush, 2000). Indigenous peoples universally use biodiversity as a buffer against environmental variability and disaster. This is especially important among indigenous societies living on margins of fragile and changing ecological, economic, and political systems. But as biodiversity itself is threatened by climate change and genetic erosion, the major defense of indigenous people against environmental variability is simultaneously affected. Their primary tool for adaptation is at risk.

In this context, some neglected crops like oca, ulluco, and mashua could maintain high adaptability in difficult environments and could gain economic value because of their agro-industrial and pharmaceutical properties (Castillo, 1995; Popenoe, 1989). The risk of genetic erosion of these species has recently prompted the development of ex situ (mainly in field genebanks) and in situ (mainly in farmers' fields) conservation programs. In the Andes, some geographical regions are found to have concentration of Andean tubers diversity (Terrazas and Valdivia, 1998). These regions present a high concentration of native oca, ulluco, and mashua varieties and are consequently recognized as diversity microcenters for Andean tubers in situ conservation. Conservation gardens are a form of in situ conservation (Maxted et al., 1997) where Andean tuber varieties found in the diversity microcenter are sown and maintained with the collaboration of farmers.

Previous studies of genetic diversity of Andean tubers described variation among cultivars for morphological traits (Rousi et al., 1989; Terrazas and Valdivia, 1998; Grau et al., 2003). More recently, molecular markers have been used to study this diversity and the inter simple sequence repeats (ISSR) technique has been successfully used to evaluate genetic diversity in cultivated accessions of the three Andean tubers species (Malice et al., 2007, 2009; Pissard et al., 2006, 2008a, b, c). Main results of this approach are linked to the evidence of heterogeneous varieties, the congruence between molecular and morphological data, and a genetic structure influenced by the geographical provenance. All these findings were explained by way of tuber management, the characteristics of the species, and the Andean agricultural system. Also, vernacular names assigned by farmers to identify cultivars are numerous and reflect the high degree of diversity (Emshwiller, 2006; Arbizu et al., 1997; Cadima Fuentes, 2006). It is known that varieties are identified according to a set of traits related to tuber and sometimes plant characteristics (Terrazas and Valdivia, 1998). Previous results on oca (Malice et al., 2007) showed that varietal structure was overall based on vernacular names, supporting peasant classification.

Genetic diversity and genetic structure of Andean tuber crop species (oca, ulluco, and mashua) have been insufficiently investigated, although understanding genetic diversity and structure of these cultivated species is a mandatory step to develop accurate conservation programs. With this is mind, our objectives were to use ISSR molecular markers to assess and compare levels of genetic diversity of Andean tuber accessions. We analyzed three species, oca, ulluco, and mashua, in an in situ germplasm collection located in the microcenter of Huanuco, Peru. We also evaluated how genetic variation was structured within each of these three Andean species and discussed the impact of Andean farming practices on crop diversity structure.

\section{MATERIALS AND METHODS Study Site and Plant Materials}

The plant material came from the microcenter of diversity of Huanuco (Fig. 1), located in Peru, in the district of Kichki, province of Huanuco (09 54'06” S, 76²6’28' E). This area, which covers approximately $160 \mathrm{~km}^{2}$, is located at an altitude ranging from 2500 to $4176 \mathrm{~m}$ above sea level. Mean temperature is $10^{\circ} \mathrm{C}$ with an annual rainfall of $1100 \mathrm{~mm} \mathrm{yr}^{-1}$ and relative humidity of $83 \%$. Soils are sandy and shallow with organic matter content less than $2 \%$.

The studied species are part of the germplasm collection constituted in 2005 from collecting missions conducted in farmers' fields throughout the microcenter and maintained in a conservation garden in Shircapata-Huayllacallán. The management of collections in the conservation garden was as follows: five tubers per accession were sown for oca, ulluco, and 
mashua, with an interrow distance of approximately $0.8 \mathrm{~m}$ and plant-to-plant distance of approximately $0.3 \mathrm{~m}$ for the oca and interrow distance of approximately $1 \mathrm{~m}$ and plant-to-plant distance of approximately $0.4 \mathrm{~m}$ for both mashua and ulluco. Crop practices, such as planting, weeding, and harvesting the tuber varieties, were similar to those used by farmers. Cattle manure, at the approximate dose of $2000 \mathrm{~kg} \mathrm{ha}^{-1}$, was added to the field. There was no chemical control of pests and diseases.

Sampling strategy enabled us to study intervarietal and intravarietal diversities conserved in the farmers' materials of the microcenter. Passport data and variety names were obtained from farmers during the collecting missions.

The samples consisted of 15 varieties of oca, 15 of ulluco, and 26 of mashua (Table 1) collected in 2006 in the conservation garden. For each variety, 1 to 3 accessions were collected (Table 1). Hereafter, we have considered a 'variety' as a set of tubers identified by farmers under a single varietal name and considered by them as a part of the same unit, which is defined by similar agro-morphological characteristics and culinary or

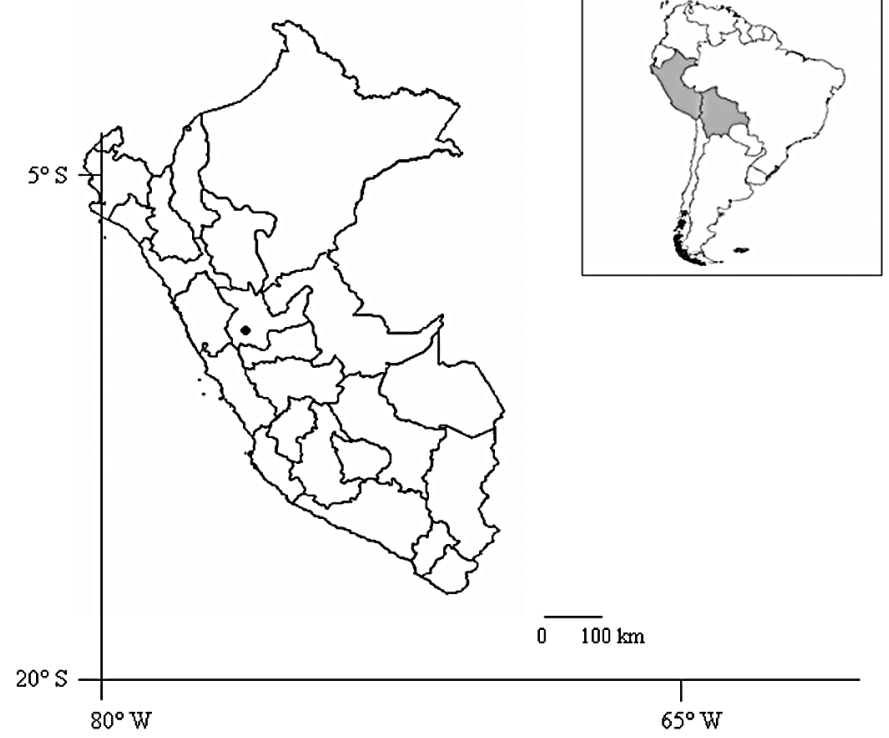

Figure 1. Map of Peru showing the location of the microcenter of Huanuco where the study was conducted.

Table 1. List of the oca, ulluco, and mashua accessions used for molecular analysis.

\begin{tabular}{|c|c|c|c|c|c|}
\hline \multicolumn{2}{|c|}{ Oca } & \multicolumn{2}{|c|}{ Ulluco } & \multicolumn{2}{|c|}{ Mashua } \\
\hline Variety & Accession number & Variety & Accession number & Variety & Accession number \\
\hline \multirow[t]{3}{*}{ Anaranjado oga } & MTPA-079 & Anaranjado redondo & MTBM-288 & Ataguepsha & MTHP-075 \\
\hline & MTPA-105 & & MTBM-264 & Cansha shagapa & MTHP-273 \\
\hline & MTPA-134 & & MTBM-222 & Chaucha rosado & MTHP-207 \\
\hline \multirow[t]{2}{*}{ Cera oga } & MTPA-023 & Anaranjado & MTBM-279 & Chicchicsa mashua & MTHP-082 \\
\hline & MTPA-081 & Wickllush & MTBM-211 & Gallopa tristan & MTHP-119 \\
\hline \multirow[t]{2}{*}{ Garwaricra } & MTPA-040 & Garwash manca & MTBM-246 & Garwash warina & MTHP-275 \\
\hline & MTPA-090 & ñawi & MTBM-201 & Garwash yana ñawi & MTHP-254 \\
\hline \multirow[t]{2}{*}{ Garwash pillao } & MTPA-109 & Garwash pikllush & MTBM-284 & Huaytash & MTHP-267 \\
\hline & MTPA-121 & & MTBM-203 & Jirca yatash & MTHP-202 \\
\hline \multirow[t]{2}{*}{ Garwuash piña } & MTPA-013 & Garwash shaipy & MTBM-255 & Limon mashua & MTHP-060 \\
\hline & MTPA-041 & & MTBM-215 & Manca ñawi & MTHP-057 \\
\hline \multirow[t]{2}{*}{ Huayta oga } & MTPA-017 & Garwash wikllush & MTBM-239 & Misha trompash & MTHP-247 \\
\hline & MTPA-083 & & MTBM-213 & Mishipa shapran & MTHP-219 \\
\hline \multirow[t]{2}{*}{ Jilguero } & MTPA-014 & Juyto sarampión & MTBM-274 & Mono mashua & MTHP-197 \\
\hline & MTPA-104 & & MTBM-257 & Puca cinta & MTHP-109 \\
\hline \multirow[t]{2}{*}{ Leche con café } & MTPA-022 & & MTBM-231 & Shagopa & MTHP-199 \\
\hline & MTPA-052 & Olluima olluco & MTBM-223 & Shulash mashua & MTHP-193 \\
\hline \multirow[t]{2}{*}{ Mio mio } & MTPA-008 & & MTBM-243 & & MTHP-255 \\
\hline & MTPA-012 & Rosado manca ñawi & MTBM-236 & Unknown 1 & MTHP-229 \\
\hline \multirow[t]{2}{*}{ Muru tornillo } & MTPA-066 & & MTBM-271 & Unknown 2 & MTHP-231 \\
\hline & MTPA-088 & & MTBM-206 & Unknown 3 & MTHP-232 \\
\hline \multirow[t]{2}{*}{ Ogllag papa oga } & MTPA-070 & Shactay olluco & МТВM-238 & Trompash & MTHP-206 \\
\hline & MTPA-113 & & MTBM-273 & Wacapa huagran & MTHP-203 \\
\hline \multirow[t]{2}{*}{ Pillahuina } & MTPA-027 & Shulash olloco & MTBM-251 & Yana ñawi & MTHP-190 \\
\hline & MTPA-040 & & MTBM-202 & & MTHP-239 \\
\hline \multirow[t]{2}{*}{ Rosado oga } & MTPA-005 & & MTBM-241 & Yana ulto & MTHP-089 \\
\hline & MTPA-011 & & MTBM-277 & Yuraj mashua & MTH-P248 \\
\hline \multirow[t]{3}{*}{ Yana pillao } & MTPA 039 & Tarma olluco & MTBM-252 & Zapallo mashua & MTHP-237 \\
\hline & MTPA 084 & & MTBM-226 & & \\
\hline & MTPA 086 & Tarmeña olluco & MTBM-234 & & \\
\hline \multirow[t]{6}{*}{ Yuraj pillao } & MTPA 044 & & MTBM-209 & & \\
\hline & MTPA 095 & Tarmeñita & MTBM-237 & & \\
\hline & & & MTBM-289 & & \\
\hline & & & MTBM-259 & & \\
\hline & & Verde juyto & MTBM-276 & & \\
\hline & & & MTBM-227 & & \\
\hline
\end{tabular}


Table 2. Inter simple sequence repeats (ISSR) primers used for DNA amplification of oca (A.), ulluco (B.), and mashua (C.), primers annealing temperature, amplified fragments number, polymorphic fragments number, and polymorphic information content (PIC values).

\begin{tabular}{|c|c|c|c|c|c|c|c|}
\hline & Primer & $\begin{array}{l}\text { Sequence } \\
5^{\prime} \rightarrow 3^{\prime}\end{array}$ & $\begin{array}{c}\text { Annealing } \\
\text { temperature }\left({ }^{\circ} \mathrm{C}\right)\end{array}$ & $\begin{array}{l}\text { Amplified } \\
\text { fragments }\end{array}$ & $\begin{array}{l}\text { Polymorphic } \\
\text { fragments }\end{array}$ & $\begin{array}{c}\text { Polymorphism } \\
\text { (\%) }\end{array}$ & $\begin{array}{l}P I C \\
\text { value }\end{array}$ \\
\hline \multirow[t]{7}{*}{ A. } & Oca-1 & $\mathrm{DHB}-(\mathrm{CGA})_{5}$ & 53,0 & 8 & 6 & 75 & 0,23 \\
\hline & Oca-2 & $(A G)_{8}-Y T$ & 47,0 & 7 & 6 & 86 & 0,23 \\
\hline & Oca-3 & $(G A)_{8}-Y C$ & 51,0 & 4 & 4 & 100 & 0,31 \\
\hline & Oca-4 & $(A G)_{8}-T$ & 50,0 & 9 & 8 & 89 & 0,36 \\
\hline & Oca-5 & $(A G)_{8}-A$ & 50,0 & 9 & 9 & 100 & 0,40 \\
\hline & Oca-6 & $(G A)_{8}-C$ & 50,0 & 9 & 8 & 89 & 0,35 \\
\hline & Oca-7 & $(T G)_{8}-Y C$ & 47,0 & 9 & 7 & 78 & 0,24 \\
\hline \multirow[t]{7}{*}{ B. } & Ulluco-1 & $\mathrm{BDB}-(\mathrm{ACA})_{5}$ & 46,0 & 9 & 5 & 56 & 0,22 \\
\hline & Ullcuo-2 & $\mathrm{DD}-(\mathrm{CCA})_{5}$ & 54,3 & 11 & 8 & 73 & 0,23 \\
\hline & Ulluco-3 & VHV-(GT) $)_{7}$ & 53,5 & 7 & 4 & 57 & 0,18 \\
\hline & Ulluco-4 & $\mathrm{BDB}-(\mathrm{CAC})_{5}$ & 55,4 & 5 & 4 & 80 & 0,27 \\
\hline & Ulluco-5 & $(A G)_{8}-Y T$ & 47,4 & 5 & 4 & 80 & 0,29 \\
\hline & Ulluco-6 & $(A G)_{8}-C$ & 47,9 & 13 & 8 & 62 & 0,15 \\
\hline & Ullcuo-7 & $(G A)_{8}-C$ & 49,4 & 8 & 6 & 75 & 0,26 \\
\hline \multirow[t]{5}{*}{ C. } & Mashua-1 & $(G A)_{8}-Y C$ & 51,0 & 5 & 5 & 100 & 0,40 \\
\hline & Mashua-2 & $(A G)_{8}-C$ & 50,0 & 9 & 8 & 89 & 0,35 \\
\hline & Mashua-3 & $(A G)_{8}-T$ & $50,0,0$ & 5 & 4 & 80 & 0,22 \\
\hline & Mashua-4 & $(G A)_{8}-A$ & 47,0 & 4 & 3 & 75 & 0,27 \\
\hline & Mashua-5 & $\mathrm{VHV}-(\mathrm{GT})_{7}-\mathrm{G}$ & 51,0 & 5 & 4 & 80 & 0,30 \\
\hline
\end{tabular}

${ }^{+} \mathrm{B}=\mathrm{G}, \mathrm{T}$ or $\mathrm{C} ; \mathrm{D}=\mathrm{G}, \mathrm{A}$ or $\mathrm{T} ; \mathrm{H}=\mathrm{A}, \mathrm{T}$ or $\mathrm{C} ; \mathrm{V}=\mathrm{G}, \mathrm{A}$ or $\mathrm{C}, \mathrm{Y}=\mathrm{C}$ or $\mathrm{T}$.

cultural purposes (Malice et al., 2007). 'Accessions' are regarded as plant samples maintained in the conservation garden.

\section{DNA Extraction and Molecular Characterization}

DNA from fresh leaves of oca, ulluco, and mashua accessions was extracted using the protocol described by Blas (2005). DNA amplification of oca samples was done in $25 \mu \mathrm{L}$ solution containing 5 ng DNA, 1x buffer (New England BioLabs, Ipswich, $\mathrm{MA}$ ), $3 \mathrm{mM} \mathrm{MgCl}, 800 \mu \mathrm{M}$ dNTPs, $0.40 \mu \mathrm{M}$ primers (Malice et al., 2007; Pissard et al., 2008c), and 2 U Taq polymerase. The thermal cycler (PTC-200, MJ Research Inc., Watertown, MA) was programmed for an initial denaturation step for $10 \mathrm{~min}$ at $95^{\circ} \mathrm{C}$ followed by 35 cycles of $30 \mathrm{sec}$ at $95^{\circ} \mathrm{C}, 45 \mathrm{sec}$ at optimized annealing temperature (Table 2) and 2 min at $72^{\circ} \mathrm{C}$, and a final extension step of $5 \mathrm{~min}$ at $72^{\circ} \mathrm{C}$.

DNA amplifications of ulluco samples were performed according to Malice et al. (2009).

DNA amplifications of mashua samples were performed in $25 \mu \mathrm{L}$ volume containing $5 \mathrm{ng}$ DNA, 1 x buffer, $2 \mathrm{mM} \mathrm{MgCl}$, $400 \mu \mathrm{M}$ dNTPs, $0.40 \mu \mathrm{M}$ primers (Pissard et al., 2008a), $0.2 \mu \mathrm{g}$ $\mu \mathrm{L}^{-1}$ bovine serum albumin (BSA), and $1 \mathrm{U}$ Taq polymerase. The thermal cycler was programmed for an initial denaturation step for $1 \mathrm{~min}$ at $94^{\circ} \mathrm{C}$ followed by 40 cycles of $1 \mathrm{~min}$ at $95^{\circ} \mathrm{C}$, $1 \mathrm{~min}$ at specific annealing temperature (Table 2) and $2 \mathrm{~min}$ at $72^{\circ} \mathrm{C}$, and a final extension step of $5 \mathrm{~min}$ at $72^{\circ} \mathrm{C}$. Amplification products were separated on 1.8\% tris-acetate buffer (TAE) agarose gels, stained with SybrSafe, and visualized under UV light.

Reproducible ISSR markers were scored for the presence (1) or absence (0) of each band. Binary matrices were, independently for each of the 3 species, subjected to data analysis.

To provide an estimate of the discriminatory power of the ISSR technique for Andean tubers oca, ulluco and mashua, a polymorphic information content (PIC) was calculated as $\mathrm{PIC}_{(\mathrm{i})}=1-\left(\mathrm{F}_{\mathrm{p}(\mathrm{i})}{ }^{2}+\mathrm{F}_{\mathrm{a}(\mathrm{i})}{ }^{2}\right)$, where $\mathrm{F}_{\mathrm{p}}$ is the presence frequency of the $\mathrm{i}^{\text {th }}$ band and $\mathrm{F}_{2}$ is the absence frequency of the $\mathrm{i}^{\text {th }}$ band. Polymorphic information content (PIC) values were then used to calculate ISSR primer index, which was generated by adding up the PIC values of all the bands amplified by the same primer.

Genetic distances between accessions were calculated with Jaccard's coefficient, using the TreeCon software (Van de Peer and de Wachter, 1994). Differences among mean genetic distances of species were tested via a one-way ANOVA, followed by a Tukey's Multiple Comparison test (Minitab software, State College, PA). Global species genetic diversity $\left(H_{\mathrm{T}}\right)$ was computed with Hickory ver. 1.0 (Holsinger et al., 2002) and compared between species using confidence interval (CI: 2.5-97.5\%) of $H_{\mathrm{T}}$. A Bayesian approach based on a Markov Chain Monte Carlo (MCMC) procedure allows estimation of genetic diversity and genetic differentiation (with confidence intervals) from dominant markers without assuming Hardy-Weinberg proportions in populations (Holsinger and Wallace, 2004). We also used the Bayesian model-based clustering method of Pritchard et al. (2000), software Structure 2.2., to identify genetic clusters within each species and to assign individual accessions to different genetic clusters or gene pools $(\mathrm{K})$ identified. We used the basic admixture model, with the assumed number of genetic cluster $(\mathrm{K})$ varying from 1 to 5 , five replicate runs per $\mathrm{K}$ value, a burning-period length of $5 \times 10^{4}$, and a post-burning simulation length of $10^{5}$. No a priori population information was used. Log likelihood of data $[\mathrm{L}(\mathrm{K})]$ and $\Delta \mathrm{K}$ statistics (rate of change between successive $\mathrm{K}$ values; Evanno et al., 2005) were calculated to infer the optimal number of clusters $(\mathrm{K})$ in the data set. Then, for each individual accession, percentage of assignment to each of the $\mathrm{K}$ genetic clusters (mean percentage of membership, q mean) was assessed. The degree of genetic differentiation $\left(F_{\mathrm{ST}}\right)$ among genetic clusters was further tested, considering the individual accessions with a cluster membership probability (q mean) higher than $80 \%$ (23 oca accessions and 31 ulloco accessions analyzed). $F_{\mathrm{ST}}$ estimates were 
computed using Hickory ver 1.00 (Holsinger et al., 2002) and compared between species using the confidence interval (CI: 2.5-97.5\%) of the $F_{\mathrm{ST}}$.

\section{RESULTS ISSR Variation}

The number of amplified fragments, the number of polymorphic fragments, and PIC values for each primer are given in Table 2. Mean PIC values per ISSR primer ranged from 0.15 for primer Ulluco-6 to 0.40 for primers Oca- 5 and Mashua-1 (Table 2). Eleven of the 22 primers showed high capacity to reveal polymorphism within the studied accessions, as their PIC values were relatively high $(\geq 0.25)$. These primers distinguished almost all accessions from one another (with the exception of four accessions of oca and two accessions of ulluco). DNA amplifications using 7, 7, and 5 primers, respectively, for oca, ulluco, and mashua, generated a total of, respectively, 55, 58, and 28 reproducible bands, from which $48(87 \%), 39(67 \%)$, and $24(85 \%)$, respectively, were polymorphic.

\section{Genetic Variation in the Three Species}

Mean genetic distance between oca accessions was $0.44 \pm 0.11$, with a range from 0 (between MTPA-023 and MTPA-081, and between MTPA-109 and MTPA-121) to 0.77 (between MTPA-008 and MTPA-104). Ulluco accessions displayed a mean genetic distance of $0.26 \pm 0.06$, with a range from 0 (between MTBM-209 and MTBM-234) to 0.42 (between MTBM-237 and MTBM-255). The mean genetic distance between accessions of mashua was $0.53 \pm 0.12$ with a range from 0.07 (between MTHP-190 and MTHP-239) to 0.82 (between MTHP-082 and MTHP-219). Mean genetic distances among species were $0.535,0.445$, and 0.262 for mashua, oca, and ulluco, respectively. The one-way ANOVA test indicated statistical differences between these genetic distances $(P<0.001)$. The Tukey test revealed that these differences were highly significant between each pair of species (95\% confidence intervals: 0.1700 to $0.1972,-0.1045$ to -0.07393 , and -0.2874 to -0.2583 for oca vs. ulluco, oca vs. mashua, and ulluco vs. mashua, respectively).

For intravarietal variability, the genetic distance varied from 0 (Cera oga and Garwash pillao) to 0.74 (Jilguero) in oca and from 0 (Tarmeña olluco) to 0.22 (Shactay olluco and Tarmeñita) in ulluco. In mashua, intravarietal sampling allowed us to evaluate intravarietal variability for the two varieties called Yana ñawi and Shulash mashua; genetic distances were, respectively, equal to 0.07 and 0.20 for these two varieties. The global genetic diversity $\left(H_{\mathrm{T}}\right)$ at the species level was equal at 0.33 for oca $(2.5-97.5 \% \mathrm{CI}=$
0.31-0.35), $0.35(2.5-97.5 \% \mathrm{CI}=0.31-0.38)$ for ulluco, and $0.46(2.5-97.5 \% \mathrm{CI}=0.43-0.47)$ for mashua. Mashua species displayed significantly higher genetic diversity than the two other species.

\section{Population Structure}

As shown in Fig. 2A and 2B, based on structure outputs, the likelihood $\mathrm{L}(\mathrm{K})$ was maximum at $\mathrm{K}=3$ for oca $([\mathrm{LnP}(\mathrm{D} \mid \mathrm{K}=3)]=-780.8)$ and at $\mathrm{K}=2$ for ulluco $([\operatorname{LnP}(\mathrm{D} \mid \mathrm{K}=2)]=-672.9)$. The highest value of $\Delta \mathrm{K}$ (oca: 71.28; ulluco: 51.09) was observed at $\mathrm{K}=2$ for both species. So $\mathrm{K}=2$ was the most likely number of distinct genetic clusters in both samples of oca and ulluco. Besides accessions assigned to one of these two genetic clusters (q mean higher than 80\%), some accessions showed intermediate values in their percentages of assignment to the two main genetic clusters (q mean lower than $80 \%$; on Fig. 3, MTPA-017 to MTPA-008 in oca and MTBM-203 

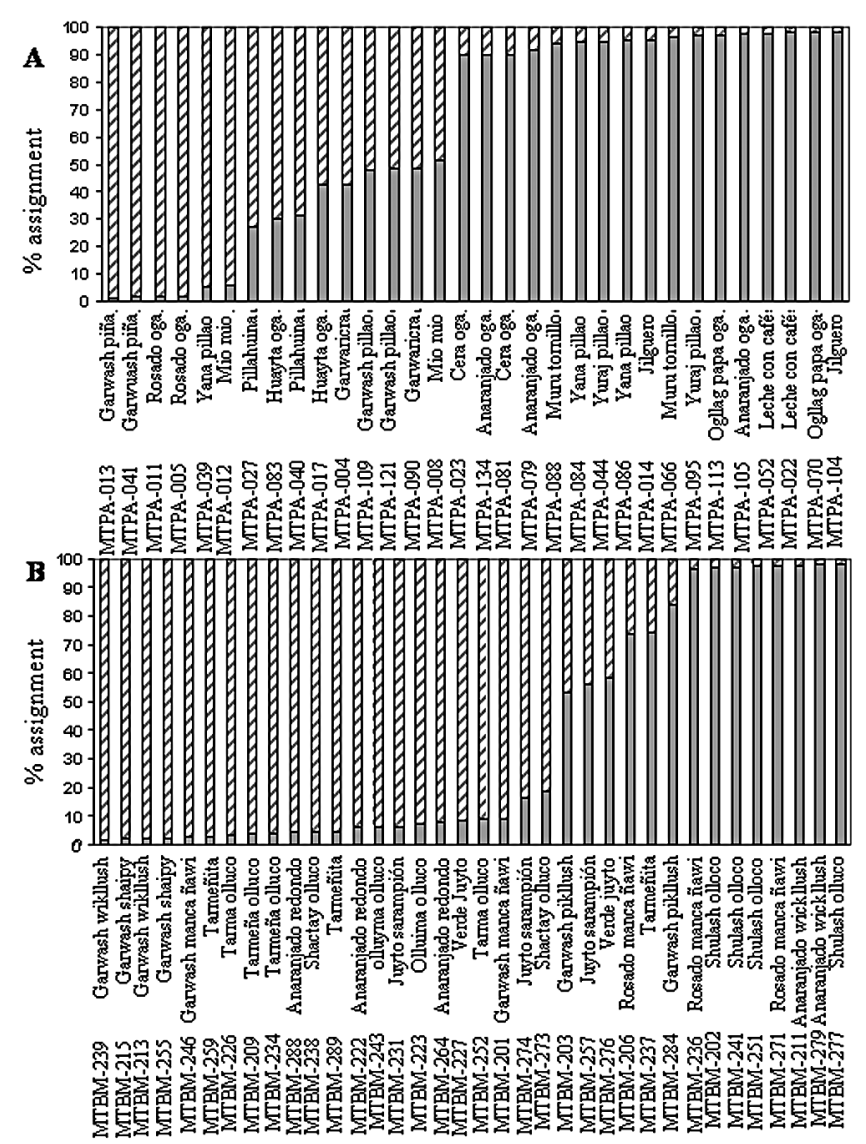

Figure 3. Percentage of assignment of the 32 oca (A) and the 36 ulluco accessions (B) into each of the two inferred genetic clusters (K) using the model-based clustering method of Pritchard et al. (2000). Accessions are indicated by their identification number and their variety name (Table 1).

to MTBM-276 in ulluco). These accessions constitute actually an intermediate cluster, between first and second clusters. Conversely, the assignment test performed on mashua revealed that all samples most probably belonged to a single genetic cluster $([\operatorname{LnP}(\mathrm{D} \mid \mathrm{K}=1)]=-403.4)$.

Results of assignment tests and pattern of genetic structure for oca (Fig. 3A) and ulluco (Fig. 3B) indicated that the individual accessions of a given variety (defined by its vernacular name) were grouped in the same genetic cluster, except for two oca varieties (Mio mio and Yana pillao) and three ulluco varieties (Rosado manca ñawi, Garwash pikllush, and Juyto sarampión), in which individual accessions clustered in two different groups.

$F_{\mathrm{ST}}$ calculations for clusters defined by structure analysis (for $\mathrm{K}=2$ ) for both oca and ulluco data sets showed that genetic differentiation between clusters was highly significant (oca: $F_{\mathrm{ST}}=0.29$; ulluco: $\left.F_{\mathrm{ST}}=0.24, P<0.001\right)$, but there were no differences between species (oca: $2.5-97.5 \% \mathrm{CI}=0.21-0.39$; ulluco: $2.5-97.5 \%$ CI $=0.15-0.35)$. Results showed that the total variation was mainly attributable to the variability within clusters (oca: 71\%; ulluco: 76\%).

\section{DISCUSSION}

The findings reported in our paper are part of a larger research program aiming to evaluate the impact of traditional agricultural practices on varietal and genetic diversity. In this context, Andean tubers constitute a representative model to study the management of genetic resources maintained in situ in neglected vegetatively propagated crop species. Indeed, in the absence of significant genetic improvement programs, the evolutionary processes of Andean tubers were mainly guided by selection pressures imposed by farmers and farming environment.

Our study showed that Andean agriculture preserved a high level of genetic diversity for three species of Andean tubers (oca, ulluco, and mashua) not only at the interspecific level but also at the intraspecific level, in terms of local varieties. This high diversity is also reflected by the large number of folk varietal names given to these three species.

Following Malice et al. (2007, 2009) and Pissard et al. $(2006,2008 \mathrm{a}, \mathrm{b}, \mathrm{c})$, this work confirmed that the ISSR technique was a reproducible and polymorphic tool to characterize genetic diversity of Andean tuber crop species, at the scale of an in situ conservation center. These molecular markers allowed successful identification of genetic variation in the three Andean tuber species (oca, ulluco, and mashua), maintained in a conservation garden located in the Peruvian diversity microcenter of Huanuco.

The mean values of genetic diversity and the genetic distance between varieties showed that the three taxa were genetically diverse. These values were higher than those observed in previous studies on Andean tubers by Malice et al. (2007, 2009) and Pissard et al. (2006, 2008a, b, c). The difference may be due to factors such as the conservation method (in situ conservation garden in our study versus ex situ collections in previous studies), resulting in more diversity within the sample from Huanuco. Del Rio et al. (1997) in potato and Tapia et al. (2004) in oca, ulluco, and mashua in Ecuador have shown similar results revealing the influence of the conservation strategy on the genetic diversity. Same observations have been reported for oca by Malice et al. (2007) as well. Furthermore, mashua possessed a higher level of genetic diversity than the two other Andean tuber species. Similar observations have been reported previously in an ex situ collection of mashua (Pissard et al., 2008a) and can be linked to specific reproductive systems and farming characteristics of each of the species. Particularly in the case of the mashua, its ability to set seed abundantly and the large number of uses might have enhanced its genetic diversity (Grau et al., 2003). Similarly, based on the samples studied from the microcenter of Huanuco, the oca and ulluco species appeared to be divided into two separate genepools each, whereas mashua seemed to be represented by a unique and more diversified genepool.

The intravarietal genetic distance was high, leading to the conclusion that, for the three species studied, varieties 
were heterogeneous. In most cases, a single variety name designated a group of individual plants that is heterogeneous, relative to the different ISSR genotypes. This type of incongruity between folk naming and ISSR genotyping systems (i.e., varietal heterogeneity) indicated that genetic variability was generally underestimated in the field. Had we only built our study on the varietal names to describe a "variety," the conclusion would have given the number of conservation units as 15 in oca, 15 in ulluco, and 26 in mashua. But, using ISSR molecular markers, we found a larger number of conservation units within each of these three species: 30 in oca, 35 in ulluco, and 28 in mashua. However, by comparing varieties as named by farmers and genotypes as distinguished by ISSR molecular markers, we noticed a general congruence between these two modes of classifications. In fact, all individual accessions with the same name presented similar ISSR data (with the exception of two oca and three ulluco varieties). Quiros et al. (1990), working on potato, and Emshwiller (2006), working on oca, also observed this consistency between folk taxonomy and isozyme and amplified fragment length polymorphism variation.

It is known that specific reproductive systems, traditional farming practices, and morphological selection applied by farmers can influence the genetic diversity of crops (Elias et al., 2001a, b; Pressoir and Berthaud, 2004; Scarcelli et al., 2006; del Castillo et al., 2007). Our results are in agreement with this expectation and are probably related to the balanced action of both (i) conservation method of the germplasm (in situ conservation garden) and (ii) evolutionary forces acting on the genetic diversity of Andean tubers across generations of farmers in traditional Andean agroecosystems (Brush et al., 1981).

Our materials had been cultivated for many generations by farmers of the microcenter of Huanuco, and had been put into the conservation garden $1 \mathrm{yr}$ before we collected samples. This period being relatively short, we can assume that genetic diversity and structure now encountered in the conservation garden faithfully represented the situation in farmers' fields. Following this, there is no doubt that traditional cultivation practices do not just maintain genetic diversity but can also act as an important source of diversity (Quiros et al., 1992; Terrazas and Valdivia, 1998; Espinoza, 2001; Terrazas and Garcia, 2003). In an in situ conservation system, populations in farmers' fields are influenced by local farming practices. Indeed, crops are not only the result of natural factors, such as mutation and natural selection, but also, and particularly, of human selection and management. Furthermore, intrinsic characteristics of the species, and notably reproductive system, also influence its genetic diversity.

Andean tubers are exclusively vegetatively reproduced and it seems very unlikely that farmers would use true seeds. Furthermore, seed production in oca remains naturally limited because of a trimorphic system of genetic incompatibility in the case of oca (Gibbs, 1976; Trognitz et al., 1998). In the case of ulluco, morphological abnormalities in the ovules and embryo sacs, combined with genetic loads (somatic mutations, especially those affecting sexual reproduction, may have appeared and be maintained during hundreds generations of vegetative reproduction) are responsible for the low seed number (Pietilä and Jokela, 1994). Grau et al. (2003) reported on mashua's capacity to exhibit both allo- and autogamy and a great botanical seed production has been reported for this species (Popenoe, 1989). Nevertheless, in traditional Andean agriculture, mashua is exclusively propagated through tubers. This situation may be explained by different factors: true-to-type breeding, reduced crop period, and prevalence of vegetatively propagated crops in Andean agriculture (Grau et al., 2003). We suggest that despite vegetative reproduction of Andean tubers, specific mating system influenced the pattern of genetic diversity and genetic structure found in the studied species, contrasting oca and ulluco versus mashua. Oca and ulluco samples were both divided into two genepools. In the particular case of mashua, a possible larger seed production, the introduction of spontaneous seedlings generated by sexual reproduction, and their introduction into the germplasm used for vegetative propagation could explain why different genepools were not differentiated in our sample.

In addition to the reproduction system, traditional Andean farming practices, agromorphological selection, and spatial arrangement affected the genetic structure of Andean tubers. In Huanuco, as in other parts of the Andean region, two features are remarkable in the management of tuber diversity: farmers cultivate many varieties of each of the three Andean tuber species (oca, ulluco, and mashua) and these varieties are sown simultaneously in each field. In fact, heterogeneous fields are particularly suitable for marginal and fluctuating environments. Moreover, such field arrangement also supports a diversity of diet, income source, yield stability, risk reduction, and limits insect and disease incidence (Terrazas and Valdivia, 1998). In the particular case of the microcenter of Huanuco, farmers plant a mixture of all types of oca, ulluco, and mashua varieties in their fields. However, oca, ulluco, and mashua are commonly separated from each others but are almost always found in neighboring plots. A major difference between the conservation garden management, compared with what is done by farmers in fields, is that Andean tubers species and varieties in the garden are sown separately to maintain the identity of the entries and to facilitate their characterization and conservation. Also, purity of accessions are verified after harvest, in the case of the conservation garden only, by a comparison with standard lists of morphological descriptors. The short history of in situ conservation in the conservation garden in Huanuco (only $1 \mathrm{yr}$ at the time of the sampling) should not have allowed high divergence between the materials 
maintained in the conservation garden compared with those cropped in farmers' fields, as already reported in the case of oca by Malice et al. (2007).

These farming practices should have particular consequences relative to genetic diversity and genetic structure of these crops that are still capable of sexual reproduction. For these species, and for mashua in our case study, that farmers maintained genotypes from sexual reproduction and used them for vegetative propagation, like in cassava (Elias et al., 2001a) or Andean potatoes (Quiros et al., 1992) could not be ruled out. As a result, new genotypes and phenotypes may be produced and selected by farmers for interesting agromorphological characteristics of the varieties. Another key element of Andean agricultural systems that influenced genetic diversity and genetic structure of Andean tubers was the exchange of tubers between farmers and communities. In fact, farmers gave or received tubers on a small scale (centers of diversity) but also on a larger scale (biodiversity fairs and markets).

In summary, our results revealed a high level of genetic diversity at the scale of a single microcenter, confirming the high genetic diversity present within the Andean neglected species oca, ulluco, and mashua and the presence of heterogeneous varieties within these species. Understanding the complex processes of creation and maintenance of genetic diversity in Andean tuber crop species is essential to improve collection management and to conserve genetic resources of neglected Andean tuber crop species threatened by genetic erosion.

\section{Acknowledgments}

This research was the result of collaboration with the University of Huanuco. We thank the "Fonds de la Recherche Fondamentale Collective" (FRFC) for financial support, and Milka Tello and Ruben Rojas for their support during the field work.

\section{References}

Altieri, M.A., and L.C. Merrick. 1987. In situ conservation of crop genetic resources through maintenance of traditional farming systems. Econ. Bot. 41:86-96.

Arbizu, C., Z. Huamán, and A. Golmirzaie. 1997. Other Andean roots and tubers. p. 39-56. In D. Fuccillo, L. Sears and P. Stapleton (ed.) Biodiversity in trust: Conservation and use of plant genetic resources in CGIAR centres. Cambridge Univ. Press, England.

Blas, R. 2005. Diversity of Arracacia species in Peru. Ph.D. thesis. Faculté des Sciences Agronomiques de Gembloux, Belgique.

Brush, S.B. 2000. Genes in the field. On-farm conservation of crop diversity. IPGRI, IDRC and Lewis Publisher, Rome, Italy.

Brush, S.B., H.J. Carney, and Z. Huaman. 1981. Dynamics of Andean potato agriculture. Econ. Bot. 35:70-88.

Cadima Fuentes, X. 2006. Tubérculos. p. 347-369. In R. Moraes, B. Øllgaard, L.P. Kvist, F. Borchsenius and H. Balslev H (ed.) Botánica Económica de los Andes Centrales. (In Spanish, with English abstract.) Universidad Mayor de San Andrés, La Paz, Bolivia.
Cárdenas, M. 1989. Manual de plantas económicas de Bolivia. 2da edición. Editorial Los Amigos del Libro. (In Spanish.) La Paz, Bolivia.

Castillo, R.O. 1995. Plant genetic resources in the Andes: Impact, conservation, and management. Crop Sci. 35:355-360.

del Castillo, C., T. Winkel, G. Mahy, and J.P. Bizoux. 2007. Genetic structure of quinoa (Chenopodium quinoa Willd.) from the Bolivian altiplano as revealed by RAPD markers. Genet. Resour. Crop Evol. 54:897-905.

Del Rio, A.H., J.B. Bamberg, Z. Huaman, A. Salas, and S.E. Vega. 1997. Assessing changes in the genetic diversity of potato genebanks. 2. In situ vs ex situ. Theor. Appl. Genet. 95:199-204.

Elias, M., O. Panaud, and T. Robert. 2001a. Traditional management of cassava morphological and genetic diversity by the Makushi Amerindians (Guyana, South America): Perspectives for on-farm conservation of crop genetic resources. Euphytica 120:143-157.

Elias, M., L. Penet, P. Vindry, D. McKey, O. Panaud, and T. Robert. 2001b. Unmanaged sexual reproduction and the dynamics of genetic diversity of a vegetatively propagated crop plant, cassava (Manihot esculenta Crantz), in a traditional farming system. Mol. Ecol. 10:1895-1907.

Emshwiller, E. 2006. Evolution and conservation of clonallypropagated crops: Insights from AFLP data and folk taxonomy of the Andean tuber oca (Oxalis tuberosa). p. 308-332. In T. Motley, N. Zerega and H. Cross (ed.) Darwin's harvest: New approaches to the origins, evolution, and conservation of crops. Colombia Univ. Press, NY, NY.

Espinoza, J.R. 2001. The traditional rural fairs and their importance as entities for the acquisition of fresh and processing products, and biodiversity. Consortium for the Sustainable Development of the Andean Ecoregion, in situ E-Conference. Available at http:// www.condesan.org/e-foros/insitu2001/J.Espinoza-english.htm (verified 28 May 2010). CIP/CONDESAN, Lima, Peru.

Evanno, G., S. Regnaut, and J. Goudet. 2005. Detecting the number of clusters of individuals using the software Structure: A simulation study. Mol. Ecol. 14:2611-2620.

Gibbs, P.E. 1976. Studies on the breeding system of Oxalis tuberosa. Flora 165:129-138.

Grau, A., D.R. Ortega, C.C. Nieto, and M. Hermann. 2003. Mashua (Tropaeolum tuberosum Ruiz \& Pav.). Promoting the conservation and use of underutilized and neglected crops. International Potato Center, Lima. International Plant Genetic Ressources Institute (IPGRI), Rome, Italy.

Hernández Bermejo, J.E., and J. León. 1992. Cultivos marginados: Otra perspectiva de 1492. (In Spanish, with English abstract.) FAO, Rome, Italy.

Holsinger, K. E., P. O. Lewis, and D. K. Dey. 2002. A Bayesian approach to inferring population structure from dominant markers. Mol. Ecol. 11:1157-1164.

Holsinger, K.E., and L.E. Wallace. 2004. Bayesian approaches for the analysis of population genetic structure: An example from Platanthera leucophaea (Orchidaceae). Mol. Ecol. 13:887-894.

Iriondo, J.M., N. Maxted, and E. Dullo. 2008. Conserving plant genetic diversity in protected areas: Population management of crop wild relatives. CABI Publishing, Wallingford.

Malice, M., N. Martin, A. Pissard, J.A. Rojas-Beltran, A. Gandarillas, P. Bertin, and J.P. Baudoin. 2007. A preliminary study of the genetic diversity of Bolivian oca (Oxalis tuberosa Mol.) varieties maintained in situ and ex situ through the utilization of ISSR molecular markers. Genet. Resour. Crop Evol. 54:685-690.

Malice, M., C.L. Villarroel Vogt, A. Pissard, C. Arbizu, and J.P. Baudoin. 2009. Genetic diversity of the Andean tuber crop 
species Ullucus tuberosus as revealed by molecular (ISSR) and morphological markers. Belg. J. Bot. 142:47-64.

Maxted, N., B.V. Ford-Lloyd, and J.G. Hawkes. 1997. Complementary conservation strategies. p. 15-39. In N. Maxted, B.V. Ford-Lloyd, and J.G. Hawkes (ed.) Plant genetic conservation. The in situ approach. Chapman \& Hall, London.

Ortega, R. 1997. Peruvian in situ conservation of Andean crops. p. 302-314. In N. Maxted, B.V. Ford-Lloyd, and J.G. Hawkes (ed.) Plant genetic conservation. The in situ approach. Chapman \& Hall, London.

Pietilä, L., and P. Jokela. 1994. Developmental abnormalities in the ovule and embryo sac of ulluco (Ullucus tuberosus) and their effect on seed set. Euphytica 75:31-39.

Pissard, A., C. Arbizu, M. Ghislain, and P. Bertin. 2008a. Influence of the geographical provenance on the genetic structure and diversity of the vegetatively propagated Andean tuber crop, mashua (Tropaeolum tuberosum), highlighted by ISSR markers and multivariate analysis methods. Int. J. Plant Sci. 169:1248-1260.

Pissard, A., C. Arbizu, M. Ghislain, A.M. Faux, S. Paulet, and P. Bertin. 2008b. Congruence between morphological and molecular markers inferred from the analysis of the intramorphotype genetic diversity and the spatial structure of Oxalis tuberosa Mol. Genetica (The Hague) 132:71-85.

Pissard, A., M. Ghislain, and P. Bertin. 2006. Genetic diversity of the Andean tuber-bearing species, oca (Oxalis tuberosa Mol.), investigated by inter-simple sequence repeats. Genome 49:8-16.

Pissard, A., J. Rojas-Beltrán, A.M. Faux, S. Paulet, and P. Bertin. 2008c. Evidence of intra-varietal genetic variability in the vegetatively propagated crop oca (Oxalis tuberosa Mol.) in the Andean traditional farming system. Plant Syst. Evol. 270:59-74.

Popenoe, H. 1989. Lost crops of the Incas. Little-known plants of the Andes with promise for worldwide cultivation. National Research Council. National Academy Press, Washington, DC.

Pressoir, G., and J. Berthaud. 2004. Population structure and strong divergent selection shape phenotypic diversification in maize landraces. Heredity 92:95-101.

Pritchard, J.K., M. Stephens, and P. Donnelly. 2000. Inference of population structure from multilocus genotype data. Genetics 155:945-959.

Quiros, C.F., S.B. Brush, D.S. Douches, K.S. Zimmerer, and G. Huestis. 1990. Biochemical and folk assessment of variability of Andean cultivated potatoes. Econ. Bot. 44:254-266.

Quiros, C.F., R. Ortega, L. van Raamsdonk, M. Herrera-Montoya, P. Cisneros, E. Schmid, and S.B. Brush. 1992. Increase of potato genetic resources in their center of diversity: The role of natural outcrossing and selection by the Andean farmer. Genet. Resour. Crop Evol. 39:107-113.
Rousi, A., R. Jokela, R. Kalliola, L. Pietila, J. Salo, and M. YliRekola. 1989. Morphological variation among clones of ulluco (Ullucus tuberosus, Basellaceae) collected in southern Peru. Econ. Bot. 43:58-72.

Scarcelli, N., S. Tostain, Y. Vigouroux, C. Agbangla, O. Daïnou, and J.L. Pham. 2006. Farmers' use of wild relative and sexual reproduction in a vegetatively propagated crop. The case of yam in Benin. Mol. Ecol. 15:2421-2431.

Tapia, C., and J. Estrella. 2001. Genetic erosion quantification in ullucus (Ullucus tuberosus Caldas), oca (Oxalis tuberosa Mol.) and mashua (Tropaeolum tuberosum R. \& P.) in agrosystems of the provinces of Cañar, Chimborazo and Tungurahua-Ecuador. Proc. Int. Symp. Managing Biodiversity in Agricultural Ecosystems, Montreal, Canada. 8-10 Nov. 2001.

Tapia, C., J. Estrella, A. Monteros, F. Valverde, M. Nieto, and J. Córdova. 2004. Manejo y Conservacion de RTAs in situ en fincas de agricultures y ex situ en el Banco de Germoplasma de INIAP (Capítulo 2). p. 31-74. In V. Barrera, C. Tapia, and A. Monteros (ed.) Raíces y Tubérculos Andinos: Alternativas para la conservación y uso sostenible en el Ecuador. Serie: Conservación y uso de la biodiversidad de raíces y tubérculos andinos: Una década de investigación para el desarrollo (1993-2003). No. 4. (In Spanish.) Instituto Nacional Autónomo de Investigaciones Agropecuarias, Centro Internacional de la Papa, Agencia Suiza para el Desarrollo y la Cooperación. Quito, Ecuador-Lima, Peru.

Terrazas, F., J.P. Baudoin, and D.P. Gonzalo. 2007. Procesos dinámicos locales para la conservación in situ de la diversidad genética de tubérculos andinos cultivados en el microcentro de Candelaria (Cocabamba, Bolivia). (In Spanish, with English abstract.) PGR Newsl. 152:1-11.

Terrazas, F., and W. Garcia. 2003. Distribución espacial y temporal de tubérculos y Raíces andinas en el Municipio de Colomi. p. 37-48. In W. García and X. Cadima (ed.) Manejo sostenible de la agrobiodiversidad de tubérculos andinos: Síntesis de investigaciones y experiencias en Bolivia. (In Spanish.) Cochabamba, Bolivia.

Terrazas, F., and G. Valdivia. 1998. Spatial dynamics of in situ conservation: Handling the genetic diversity of Andean tubers in mosaic systems. PGR Newsl. 114:9-15.

Trognitz, B.R., M. Hermann, and S. Carrión. 1998. Germplasm conservation of oca (Oxalis tuberosa Mol.) through botanical seed. Seed formation under a system of polymorphic incompatibility. Euphytica 101:133-141.

Van de Peer, Y., and Y. de Wachter. 1994. TREECON for windows: A software package for the construction and drawing of evolutionary trees for the Microsoft environment. Comput. Appl. Biosci. 10:569-570. 